\title{
The female mouse is resistant to mild vitamin $B_{3}$ deficiency
}

\author{
Inge van der Stelt ${ }^{1} \cdot$ Wenbiao Shi $^{1,2} \cdot$ Melissa Bekkenkamp-Grovenstein ${ }^{1} \cdot$ Rubén Zapata-Pérez ${ }^{3}$. \\ Riekelt H. Houtkooper ${ }^{3} \cdot$ Vincent C. J. de Boer $^{1} \cdot$ Maria A. Hegeman $^{4} \cdot$ Jaap Keijer $^{1}$
}

Received: 25 August 2020 / Accepted: 28 June 2021 / Published online: 2 August 2021

(c) The Author(s) 2021

\begin{abstract}
Purpose Vitamin $\mathrm{B}_{3}$ provides nicotinamide adenine dinucleotide $\left(\mathrm{NAD}^{+}\right)$, an essential coenzyme in oxidoreductase reactions. Severe vitamin $B_{3}$ deficiency leads to the disease Pellagra, while mild vitamin $B_{3}$ deficiency has been linked to age-related and metabolic diseases. Mild vitamin $\mathrm{B}_{3}$ deficiency is understudied, especially in females. Therefore, we examined how female mice responded to a diet that induced mild vitamin $\mathrm{B}_{3}$ deficiency in male mice.

Methods Female C57BL/6RccHsd mice were subjected for 18 weeks to a diet without vitamin $\mathrm{B}_{3}$ and low but sufficient tryptophan $(0.115 \%)(0 \mathrm{NR})$ and were compared to control female mice on the same diet with the reference dose of vitamin $\mathrm{B}_{3}$ (30NR, $30 \mathrm{mg}$ nicotinamide riboside/ $\mathrm{kg}$ diet).

Results In the female mice, no differences between the two dietary groups were found in liver nicotinamide mononucleotide (NMN) levels, body composition, whole body energy and substrate metabolism measured by indirect calorimetry, or liver triacylglycerol metabolism. Expression of seven genes that previously were shown to respond to mild vitamin $\mathrm{B}_{3}$ deficiency in male white adipose tissue were not differentially expressed between the female dietary groups, neither was insulin sensitivity. Conclusion We concluded that the female 0NR mice were not vitamin $\mathrm{B}_{3}$ deficient; the role of age, sex and health status is discussed. Demonstrated by clear differences between females and males, the latter showing mild deficiency under the same conditions, this study highlights the importance of studying both sexes.
\end{abstract}

Keywords Vitamin $B_{3}$ deficiency $\cdot$ Nicotinamide riboside $\cdot$ Tryptophan $\cdot$ Male-female differences $\cdot$ Insulin sensitivity . White adipose tissue

Jaap Keijer

jaap.keijer@wur.nl

1 Human and Animal Physiology, Wageningen University, PO Box 338, 6700 AH Wageningen, The Netherlands

2 Present Address: Key Laboratory of Precision Nutrition and Food Quality, Department of Nutrition and Health, China Agricultural University, Beijing 100083, China

3 Laboratory Genetic Metabolic Diseases, Amsterdam Gastroenterology, Endocrinology, and Metabolism, Amsterdam Cardiovascular Sciences, Amsterdam UMC, University of Amsterdam, Meibergdreef 9, 1105 AZ Amsterdam, The Netherlands

4 Present Address: Educational Consultancy and Professional Development, Faculty of Social and Behavioural Sciences, Utrecht University, 3584 CS Utrecht, The Netherlands

\section{Introduction}

Oxidised nicotinamide adenine dinucleotide $\left(\mathrm{NAD}^{+}\right)$is essential as a coenzyme in oxidoreductase reactions, and it functions as a consumed ligand in, for example, sirtuinand poly(ADP-ribose) polymerase-related activities [1, 2]. Dietary intake of vitamin $\mathrm{B}_{3}$, which exists in various forms, and de novo synthesis from the essential amino acid tryptophan, via the kynurenine pathway, are of essence to produce $\mathrm{NAD}^{+}$. Nicotinic acid and nicotinamide are forms of vitamin $\mathrm{B}_{3}$ which can generate $\mathrm{NAD}^{+}$via the Preiss-handler pathway and the $\mathrm{NAD}^{+}$salvage pathway, respectively; the more recently discovered nicotinamide riboside (NR) shares metabolic steps with nicotinamide, however, distinctly using nicotinamide riboside kinase 1 or 2 (NRK1/2) [3, 4].

Vitamin $\mathrm{B}_{3}$ has gained interest since it was shown that an increased intake improved health, for example, in hypercholesterolaemic patients. Nicotinic acid supplementation was reported in human studies to reduce, amongst other 
parameters, circulating levels of total cholesterol, LDL to HDL ratio, and triacylglycerols [5-9] towards a more healthy lipid profile. Using a partly different pathway compared to nicotinic acid expected to result in less side effects, NR supplementation showed a potent increase in (mitochondrial) $\mathrm{NAD}^{+}$levels in vitro and in vivo [10]. Amongst other parameters, the liver of mice fed a high-fat diet supplemented with a high dose of NR $(400 \mathrm{mg} / \mathrm{kg} / \mathrm{day})$ showed a $40 \%$ reduction in triacylglycerol content, and decreased cholesterol levels were found, resulting in an improved lipid profile in the NR supplemented mice [10].

Contrasting vitamin $\mathrm{B}_{3}$ supplementation, severe vitamin $\mathrm{B}_{3}$ deficiency results in Pellagra, a disease characterised by dermatitis, diarrhoea, dementia, and finally death [11, 12]. Although mostly prevented by education on food choices and food preparation, the disease still exists in poorer countries and in patients with severe malnutrition due to, for example, anorexia or severe alcoholism. Effects of mild, subclinical deficiency are less clear, but may be relevant on a population level, as it may contribute to metabolic diseases as well as age-related diseases. Mild vitamin $\mathrm{B}_{3}$ deficiency, not inducing Pellagra, was, for example, shown to affect insulin sensitivity [13]. Next to this, the discovered age-related decline in $\mathrm{NAD}^{+}$levels has been related to age-related diseases such as Alzheimer's disease, where treatment with vitamin $B_{3}$ showed beneficial effects [14-16]. Therefore, it is important to understand, and hence investigate, the effects of a mild vitamin $\mathrm{B}_{3}$ deficiency, and to discover its early signs. In a recent study in male C57BL/6JRccHsd mice, we found that mild vitamin $\mathrm{B}_{3}$ deficiency emerged after 18 weeks on a diet without vitamin $B_{3}$. In particular, in the male mice on the deficient diet insulin sensitivity was decreased, liver nicotinamide mononucleotide (NMN) levels were lower and in white adipose tissue seven genes were differentially expressed, compared to male mice on the same diet with vitamin $B_{3}$ [17]. In this study, $N R$ was used as vitamin $B_{3}$ in the control diet at the AIN93 recommended level $(30 \mathrm{mg} / \mathrm{kg}$ diet) [18], which we recently confirmed as optimal dose to support health in mice [13].

While vitamin $B_{3}$ deficiency studies are rare, this is even more true for female mice, despite marked metabolic differences between the sexes $[19,20]$. Therefore, with this study, we wanted to increase the rather poor knowledge of a mild vitamin $\mathrm{B}_{3}$ deficiency and specifically gain knowledge on females. We subjected female mice to the exact circumstances causing mild vitamin $\mathrm{B}_{3}$ deficiency in male mice. We measured body composition and related parameters, energy metabolism and metabolic flexibility. Next to this, we analysed if the positive relation between lipid profile and vitamin $B_{3}$ supplementation, as found by others, holds in case of a mild vitamin $B_{3}$ deficiency; i.e. whether a worsening of the lipid profile occurred. We investigated the expression of seven genes in the white adipose tissue of the female mice that were previously found to be responsive to mild vitamin $\mathrm{B}_{3}$ deficiency in males. To define the $\mathrm{NAD}^{+}$status, we measured the abundance of $\mathrm{NAD}^{+}$and related metabolites in liver. Lastly, insulin sensitivity was determined in the females and compared to the male insulin sensitivity parameters.

\section{Materials and methods}

\section{Animal study}

The animal experiment was ethically approved (DEC2016033b) and performed in full accordance with national and EU regulations. This independent experiment was performed in parallel with an experiment with male mice [17], in which the exact same conditions induced a mild vitamin $\mathrm{B}_{3}$ deficiency. Twenty-four C57BL/6JRccHsd female mice (Envigo, Horst, the Netherlands) were individually housed ( $12 \mathrm{~h}$ light-dark cycle, $23 \pm 1{ }^{\circ} \mathrm{C}, 55 \pm 15 \%$ humidity), with ad libitum access to feed and water, unless indicated otherwise. Eleven-week-old mice were accustomed for 2 weeks to the control (30NR) moderately high-fat diet containing $40 \%$ energy from fat, $41 \%$ energy from carbohydrates, and $19 \%$ energy from proteins, and importantly $30 \mathrm{mg}$ NR per $\mathrm{kg}$ diet as vitamin $\mathrm{B}_{3}$ source combined with a low but sufficient level $(0.115 \%)$ of l-tryptophan (Research Diet Services, Wijk bij Duurstede, the Netherlands, see supplementary Table 1 for full ingredient information). Subsequently, mice were stratified based on body weight into two experimental groups $(n=12)$ which received either the control 30NR diet (30NR) or the same diet, except that NR was omitted (0NR). Intended to study recovery from vita$\min \mathrm{B}_{3}$ deficiency, an additional group fed the 0NR diet for 15 weeks followed by the 30NR diet during the last 3 weeks $(0+30 \mathrm{NR})$ was also studied $(n=12)$. Body weight and feed intake as well as lean and fat mass (by NMR, EchoMRI, Houston, USA) were measured weekly. Indirect calorimetry was performed in week 14 , and an oral glucose tolerance test was conducted in week 17; blood and plasma were collected for glucose and insulin measurements, respectively. Mice were killed after 18 weeks on the diet by decapitation in a fed state, i.e. four hours after refeeding with $1.8 \mathrm{~g}$ of diet at the start of the light phase. Whole blood was collected in serum tubes (Greiner Bio-one, Longwood, USA), and serum was obtained by centrifugation at $3000 \mathrm{~g}, 4^{\circ} \mathrm{C}$ for $10 \mathrm{~min}$, aliquoted and stored at $-80^{\circ} \mathrm{C}$. White adipose tissue and liver were snap frozen into liquid nitrogen and stored at $-80{ }^{\circ} \mathrm{C}$. 


\section{Indirect calorimetry}

Oxygen $\left(\mathrm{O}_{2}\right)$ consumption and carbon dioxide $\left(\mathrm{CO}_{2}\right)$, hydrogen and methane production were measured in week 14 using a PhenoMaster System (TSE Systems, Bad Homburg, Germany), as described [13, 21]. Respiratory exchange ratio (RER) and energy expenditure were obtained using TSE software. Respiratory exchange ratio (RER) was defined as $\mathrm{CO}_{2}$ production ( $\mathrm{VCO} 2$ ) divided by $\mathrm{O}_{2}$ consumption $\left(\mathrm{VO}_{2}\right)$, and energy expenditure $(\mathrm{kcal} / \mathrm{h})$ was calculated with TSE Software 4.2.3 using the equation: Energy expenditure $=\left[3.941 \times \mathrm{VO}_{2}+1.106 \times \mathrm{VCO}_{2}\right] / 1000$. After an adaptation period of $20 \mathrm{~h}$, the mice were measured during ad libitum feeding for $24 \mathrm{~h}$. Then, a fasting and refeeding challenge was conducted to assess metabolic flexibility based on the change in RER. The mice were given $1.5 \mathrm{~g}$ of the experimental diet (0NR or $30 \mathrm{NR}$, depending on the experimental group) right before the dark period, which led to a fasted state during the light phase, where the response to refeeding was examined by providing the mice with $1.8 \mathrm{~g}$ of the corresponding experimental diet. $\triangle$ RER was calculated by subtracting average fasted RER (7:00-16:00) from average refed RER (17:30 h-01:00).

\section{Oral glucose tolerance test}

An oral glucose tolerance test was performed in week 17, as described [21]. Briefly, after $6 \mathrm{~h}$ fasting, blood glucose was measured using blood from the distal end of the tail of the mice, at time point $t=0$ and after oral glucose gavage ( $2 \mathrm{~g} / \mathrm{kg}$ body weight) at $t=15,30,60,90$, and 120 min using a Freestyle blood glucose metre (Abbott Diabetes Care, Hoofddorp, The Netherlands). Plasma was collected at $t=0$, 15, and 30 min using Microvette CB 300 tubes with potassium EDTA (1.6 mg EDTA/mL blood, Sarstedt, Etten-Leur, The Netherlands), which was centrifugated for $20 \mathrm{~min}$ at $2000 \mathrm{~g}, 4^{\circ} \mathrm{C}$. This plasma was the input for the mouse insulin ELISA kit (Crystal Chem, Downers Grove, USA), measuring insulin according to instructions. To assess insulin sensitivity, homeostatic model assessment of insulin resistance (HOMA-IR) was used and calculated as (fasting glucose in $\mathrm{mmol} / \mathrm{L} \times$ fasting insulin in $\mathrm{mU} / \mathrm{L}) / 14.1$ [22].

\section{Triacylglycerols and free fatty acids}

Serum free fatty acids were measured in duplicate using a NEFA-HR kit (Wako chemical GmbH, Neuss, Germany) according to the manufacturer's instructions. In short, $5 \mu \mathrm{l}$ serum was incubated with $200 \mu \mathrm{l}$ reagent $\mathrm{R} 1$ for $10 \mathrm{~min}$ at $37^{\circ} \mathrm{C}$, which was subsequently incubated with $100 \mu \mathrm{l}$ reagent $\mathrm{R} 2$ for $10 \mathrm{~min}$ at $37^{\circ} \mathrm{C}$, after which absorbance at $546 \mathrm{~nm}$ was measured using a synergy HT microplate reader (BioTek instruments Inc., Winooski, VT, USA) and corrected for background absorbance at $660 \mathrm{~nm}$. Standard curves of NEFA standard solution (Wako chemical GmbH) were used for quantification of free fatty acids. Liver triacylglycerols were measured in triplicate using a triglyceride liquicolor mono kit (Human, Wiesbaden, Germany), according to the manufacturer's instructions. In short, liver was ground in liquid nitrogen and homogenised in homogenization buffer (10 mM Tris, $2 \mathrm{mM}$ EDTA, and $250 \mathrm{mM}$ sucrose). $4 \mu \mathrm{l}$ of homogenate was incubated with $100 \mu$ l of reagent for $45 \mathrm{~min}$, after which absorbance at $500 \mathrm{~nm}$ was measured using a synergy HT microplate reader (BioTek instruments Inc., Winooski, VT, USA). Standard curves of triacylglycerol standard supplied in the kit was used for quantification of triacylglycerol levels. Triacylglycerol levels were expressed per amount of total protein in the homogenates, which was measured using the DC-protein kit (Bio-rad).

\section{RNA Isolation and CDNA synthesis}

Total RNA was isolated from white adipose tissue and liver with a RNeasy Mini kit (Qiagen, Venlo, the Netherlands), according to the manufacturer's instructions. RNA yield and purity were checked using a Nanodrop spectrophometer (IsoGen Life Science, Maarsen, The Netherlands) and RNA integrity was verified using a TapeStation (Agilent, Santa Clara, CA, USA). One microgram of RNA was converted to cDNA using the iScript cDNA synthesis kit (Bio-Rad, Veenendaal, The Netherlands).

\section{Real time quantitative reverse transcription polymerase chain reaction (RT-qPCR)}

RT-qPCR was performed using SYBR Green Supermix (Bio-Rad), according to the manufacturer's instructions with an end volume of $25 \mu \mathrm{l}$, using a CFX96 real time PCR detection system (Bio-rad). Standard curves of pooled samples, negative controls, duplicates, melting profiles, R2 and PCR efficiency were used for validation of each run according to the MIQE guidelines [23].

Gene expression of the following genes was analysed in liver: apolipoprotein B (Apob), diacylglycerol O-acyltransferase 2 (Dgat2), microsomal triglycerol transfer protein $(M t t p)$ using reference genes ribosomal protein S15 (Rps15), hypoxanthine guanine phosphoribosyl transferase (Hprt) and calnexin (Canx) for normalisation. In white adipose tissue, mRNA expression of the following genes was measured: acidic (leucine-rich) nuclear phosphoprotein 32 family, member A (Anp32A), mitogen-activated protein kinase kinase 1 (Map2kl), mitogen-activated protein kinase 1 (Mapk1), 5, 10-methenyltetrahydrofolate synthetase (Mthfs), 5, 10-methenyltetrahydrofolate synthetase-like (Mthfsl), quinoid dihydropteridine reductase ( $Q d p r)$, solute carrier family 2 (facilitated glucose transporter), member 
4 (Slc2a4), tyrosine kinase, non-receptor, 2 (Tnk2) using reference genes beta- 2 microglobin (B2m) and Rps15. An overview of all genes, primers and their sequences used can be found in Supplementary Table 2. Relative gene expression was expressed as the normalized expression values of the 0NR mice compared to the mean of the values of the $30 \mathrm{NR}$ control mice set at 1 .

\section{Mass spectrometry measurements}

Metabolomics analysis was performed as previously described with minor modifications [24]. 6-8 mg of freeze-dried liver was metabolically quenched using icecold methanol $(500 \mu \mathrm{l})$ and diluted with Milli-Q water $(500 \mu \mathrm{l})$ containing the internal standards, $\mathrm{D}_{5}$-glutamine, $\mathrm{D}_{5}$-phenylalanine, adenosine- $-{ }^{15} \mathrm{~N}_{5}-$ monophosphate, adenosine- $-{ }^{15} \mathrm{~N}_{5}$-triphosphate, and guanine- $-{ }^{15} \mathrm{~N}_{5}$-triphosphate $(5 \mu \mathrm{m}$ each). Samples were then homogenised using a TissueLyser II (Qiagen, Hilden, Germany) for $5 \mathrm{~min}$ at a frequency of 30 times per second. Phase separation was obtained by chloroform addition $(1 \mathrm{~mL})$ followed by thorough mixing and centrifugation at $16,000 \mathrm{~g}$ for $5 \mathrm{~min}$ at $4{ }^{\circ} \mathrm{C}$. The polar upper phase was then transferred to $1.5 \mathrm{~mL}$ tubes and dried in a vacuum concentrator at $60{ }^{\circ} \mathrm{C}$. The pellets obtained after concentration were dissolved in $100 \mu$ methanol/water $(6 / 4 ; v / v)$.

Metabolite analysis was performed using a Waters Acquity ultra-high performance liquid chromatography system coupled to a Bruker Impact II ${ }^{\mathrm{TM}}$ Ultra-High Resolution Qq-Time-Of-Flight mass spectrometer. Chromatography was performed in a SeQuant ZIC-cHILIC column (PEEK $100 \times 2.1 \mathrm{~mm}, 3 \mu \mathrm{m}$ particle size; Merck, Kenilworth, NJ, USA) at $30{ }^{\circ} \mathrm{C}$. The LC method consisted in a gradient running at $0.25 \mathrm{~mL} / \mathrm{min}$ from $100 \%$ mobile phase $\mathrm{B}(9: 1$ acetonitrile:water with $5 \mathrm{mM}$ ammonium acetate $\mathrm{pH} 8.2$ ) to $100 \%$ mobile phase A (1:9 acetonitrile:water with $5 \mathrm{mM}$ ammonium acetate $\mathrm{pH}$ 6.8) in $28 \mathrm{~min}$, followed by a reequilibration step at 100\% B of $5 \mathrm{~min}$. Mass spectrometry data were acquired both in negative and positive ionisation modes over the range of $m / z 50-1200$. Data from full-scan mass spectrometry mode was analysed using Bruker TASQ software (Version 2.1.22.1 1065). All reported metabolite intensities were normalised to tissue weight, as well as to internal standards with comparable retention times and response in the mass spectrometer.

\section{Statistics}

Graphpad Prism version 5.04 (Graphpad Software, San Diego, CA, USA) was used for statistical analysis. Comparisons between normally distributed 30NR and 0NR data were done with an unpaired Student's $t$-test (body parameters, gene expression, blood parameters), when not normally distributed a Mann-Whitney $U$ test was used. For measurements repeated over time two-way ANOVA was used with Bonferroni post-hoc testing (indirect calorimetry measurements, and oral glucose tolerance test). Differences were considered significant for $p<0.05$.

\section{Results}

\section{Body composition and food intake}

Total body weight and body composition measured by echoMRI did not show statistical differences between the female mice supplied the diet with a reference amount of vitamin $\mathrm{B}_{3}$ (30NR; $30 \mathrm{mg} \mathrm{NR} / \mathrm{kg}$ ) and mice on the same diet but without vitamin $\mathrm{B}_{3}(0 \mathrm{NR})$, both diets with a minimal (essential) level of tryptophan (Table 1). At the start of the experiment, body weight $(21.0 \mathrm{~g}$ for $0 \mathrm{NR}$ and $20.7 \mathrm{~g}$ for 30NR, $p=0.544)$ and body composition (11.1\% adiposity for $30 \mathrm{NR}$ and $11.2 \%$ adiposity for $0 \mathrm{NR}, p=0.885$ ) were not different nor were any differences observed at any of the intermediate timepoints (data not shown). No differences are seen in serum leptin levels at the end of the study $(0.781 \mu \mathrm{g} / \mathrm{mL}$ for $30 \mathrm{NR}$ and $0.544 \mu \mathrm{g} / \mathrm{mL}$ for $0 \mathrm{NR}$, $p=0.126$ ), confirming that the diets did not affect fat mass. Similarly, total food intake was comparable between the 0NR and 30NR female mice. Therefore, it can be concluded that the depletion of NR from the diet for 18 weeks did not affect body composition and food intake in the female mice. Similarly, no obvious visual differences between the two dietary groups in behaviour or health were observed during the study and tissues appeared visually healthy upon section.

Table 1 Body composition and food intake of 30NR and 0NR mice at the end of the study

\begin{tabular}{lccc}
\hline & $30 \mathrm{NR} \pm \mathrm{SD}$ & $0 \mathrm{NR} \pm \mathrm{SD}$ & $p$ value \\
\hline Body weight $(\mathrm{g})$ & $31.6 \pm 4.6$ & $29.4 \pm 4.4$ & 0.231 \\
Lean mass $(\mathrm{g})$ & $19.1 \pm 1.2$ & $19.1 \pm 1.2$ & 0.946 \\
Fat mass $(\mathrm{g})$ & $10.8 \pm 3.8$ & $8.6 \pm 3.4$ & 0.149 \\
Adiposity $(\%)$ & $33.3 \pm 7.6$ & $28.3 \pm 7.6$ & 0.127 \\
Total food intake $(\mathrm{g})$ & $343.9 \pm 31.4$ & $327.3 \pm 39.1$ & 0.262
\end{tabular}

Endpoint measurements ( $t=18$ weeks) with no differences between body weight, fat mass, and lean mass. Adiposity is calculated using fat mass and body weight. Total food intake is the accumulated food intake over 18 weeks. 30NR mice $(n=12)$ had $30 \mathrm{mg} / \mathrm{kg}$ nicotinamide riboside in their diets, $0 \mathrm{NR}$ mice $(n=12)$ were on diets without nicotinamide riboside and other forms of vitamin $\mathrm{B}_{3} . S D$ standard deviation 


\section{Whole body metabolism}

The effect of omitting dietary NR for 18 weeks on whole body energy metabolism was measured using indirect calorimetry. Fat and carbohydrate oxidation, as measured by RER, did not show significant differences between 0 and 30NR female mice when analysed by two-way ANOVA (Fig. 1A), although metabolism of the 0NR mice tended to be skewed towards carbohydrate metabolism. The refeeding challenge, used as a measure for metabolic flexibility, was borderline significant (Fig. 1B). The energy expenditure was slightly lower in the 0NR mice, significant at two timepoints, however, ANOVA testing resulted in no overall difference between the two female dietary groups (Fig. 1C). Hydrogen excretion measurements were overall low, indicating no or small activation of hydrogen excreting microbiota [25], similar in the 0NR mice and the control 30NR mice (Fig. 1D).

\section{A}

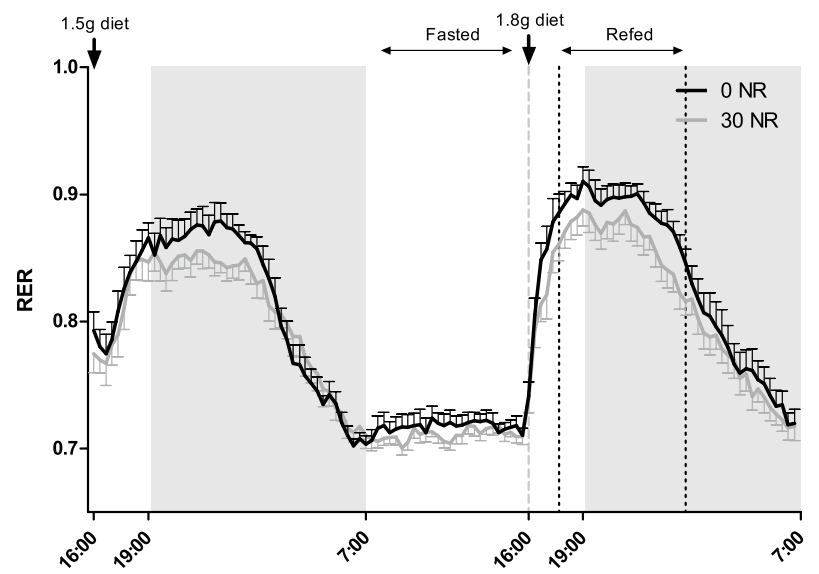

C

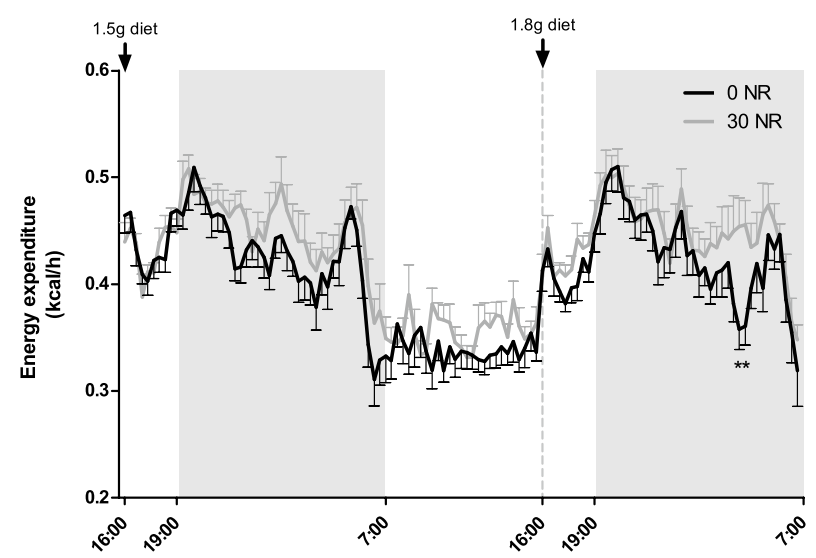

Fig. 1 Indirect calorimetry measurements shows similar RER, energy expenditure and hydrogen excretion in mice on a $30 \mathrm{mg} \mathrm{NR} / \mathrm{kg}$ diet (30NR) or no NR (0NR). a Respiratory exchange ratio (RER), b $\triangle$ RER, calculated by subtracting average refed RER (17:30 h-01:00)
Methane excretion was at detection levels in both dietary groups (data not shown). Taken together, the diet without vitamin $\mathrm{B}_{3}$ did not compromise whole body metabolism nor, more specifically, metabolic flexibility in the female mice.

\section{Triacylglycerol metabolism}

Supplementation of NR was shown to induce positive effects towards a healthier lipid profile. To analyse the hypothesised negative effects on health induced by depletion of NR, we analysed the triacylglycerol metabolism in the two groups of mice. Serum free fatty acids and liver triacylglycerols were not different in the $0 \mathrm{NR}$ mice compared to the $30 \mathrm{NR}$ mice, indicating no difference in the uptake and excretion of fatty acids in the liver of the female mice (Fig. 2A and C). Similarly, no differences in gene expression of hepatic Apob, Dgat2, and Mttp were found (Fig. 2D-F).
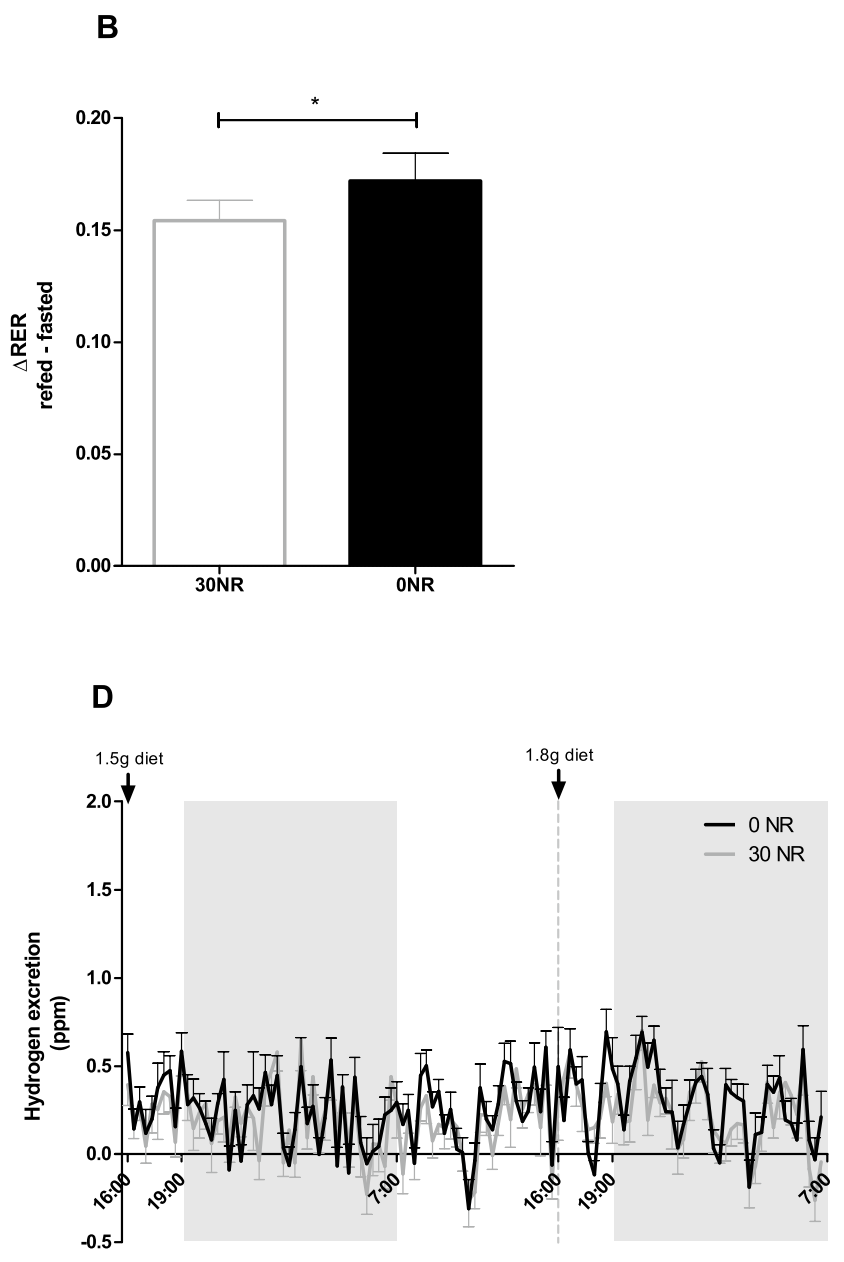

by average fasted RER (7:00-16:00), $\mathbf{c}$ Energy expenditure, $\mathbf{d}$ Hydrogen excretion, measured at week 14 of the study. Significant differences of $p<0.05$ are indicated with $*$. Values are means \pm SEM $(n=12)$ 


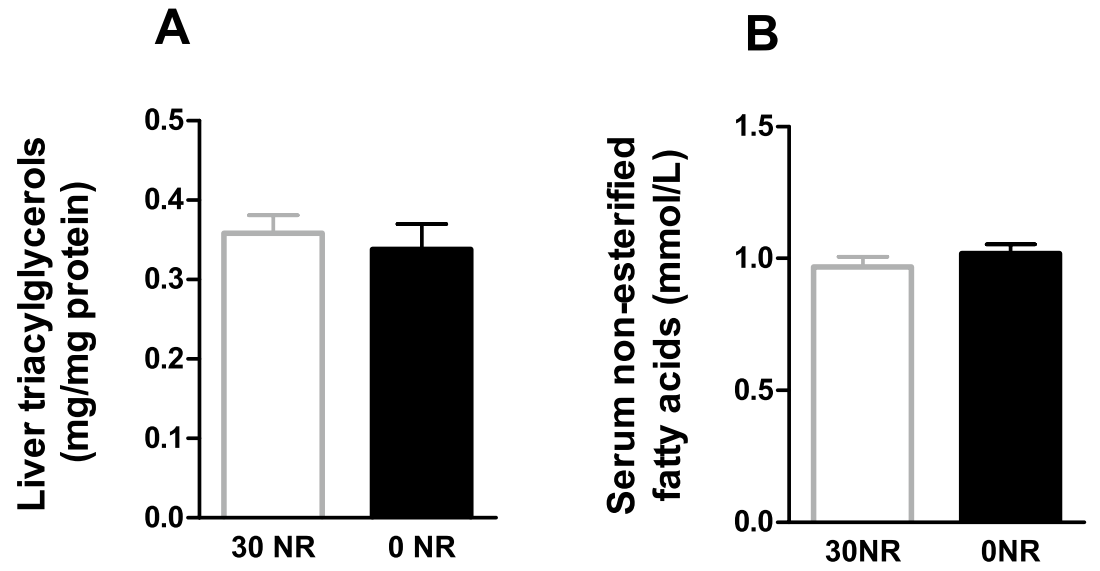

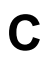

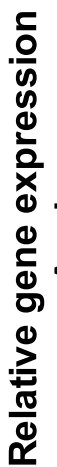
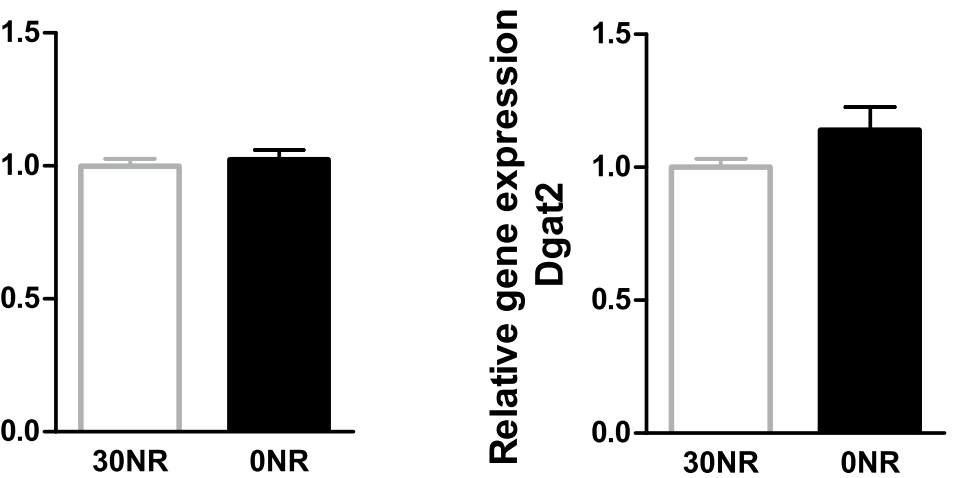

E

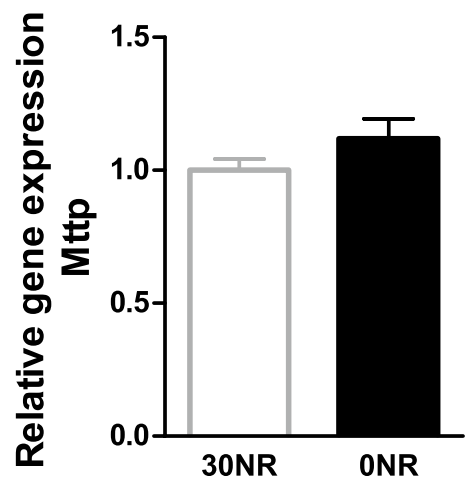

Fig. 2 Triacylglycerol metabolism in mice without vitamin $B_{3}$ in the diet (0NR) compared to mice fed $30 \mathrm{mg} \mathrm{NR} / \mathrm{kg}$ diet $(30 \mathrm{NR})$ at the end of the study ( $t=18$ weeks). a Triacylglycerols measured in liver, b Non-esterified fatty acids measured in serum, and hepatic

\section{White adipose tissue genes responsive to mild vitamin $B_{3}$ deficiency}

We previously published the differential expression of seven genes in white adipose tissue of mild vitamin $\mathrm{B}_{3}$ deficient male mice [17]. In contrast to what we observed for the male mice, the expression profile of these seven genes in white adipose tissue of the $0 \mathrm{NR}$ female mice of the current study was not different from the control 30NR female mice (Fig. 3).

\section{$\mathrm{NAD}^{+}$and its metabolites}

To determine whether the absence of NR intake would affect the $\mathrm{NAD}^{+}$metabolite profile, we measured the abundance of several $\mathrm{NAD}^{+}$-related metabolites in the liver. No differences between the dietary groups were found in methylnicotinamide (MeNAM), $\mathrm{NAD}^{+}$or its reduced form NADH, gene expression: c Apolipoprotein B (Apob), d Diacylglycerol O-acyltransferase 2 (Dgat2), e Microsomal triglycerol transfer protein (Mttp). Values are means $\pm \operatorname{SEM}(n=12)$

oxidised or reduced nicotinamide dinucleotide phosphate $\left(\mathrm{NADP}^{+}\right.$and NADPH), or nicotinamide (NAM) (Fig. 4A-F). Importantly, the levels of NMN, a key metabolite involved in $\mathrm{NAD}^{+}$recycling from $\mathrm{NR}$, which was decreased in livers of male mice on the same diet, was not different between the 0NR and 30NR female mice (Fig. 4G). The phosphoribosyl pyrophosphate (PRPP) level was increased in the 0NR mice compared to the 30NR mice (Fig. 4H), while no differences between these groups were detected for ribose-5-phosphate or tryptophan (Fig. 4I, J). Altogether, these results suggest that the diets used in this study do not have an impact on $\mathrm{NAD}^{+}$metabolism in female mice.

\section{Insulin sensitivity}

As female mice did not show differences in white adipose tissue expression of seven genes that were found to be responsive in males upon the same dietary intervention, and 


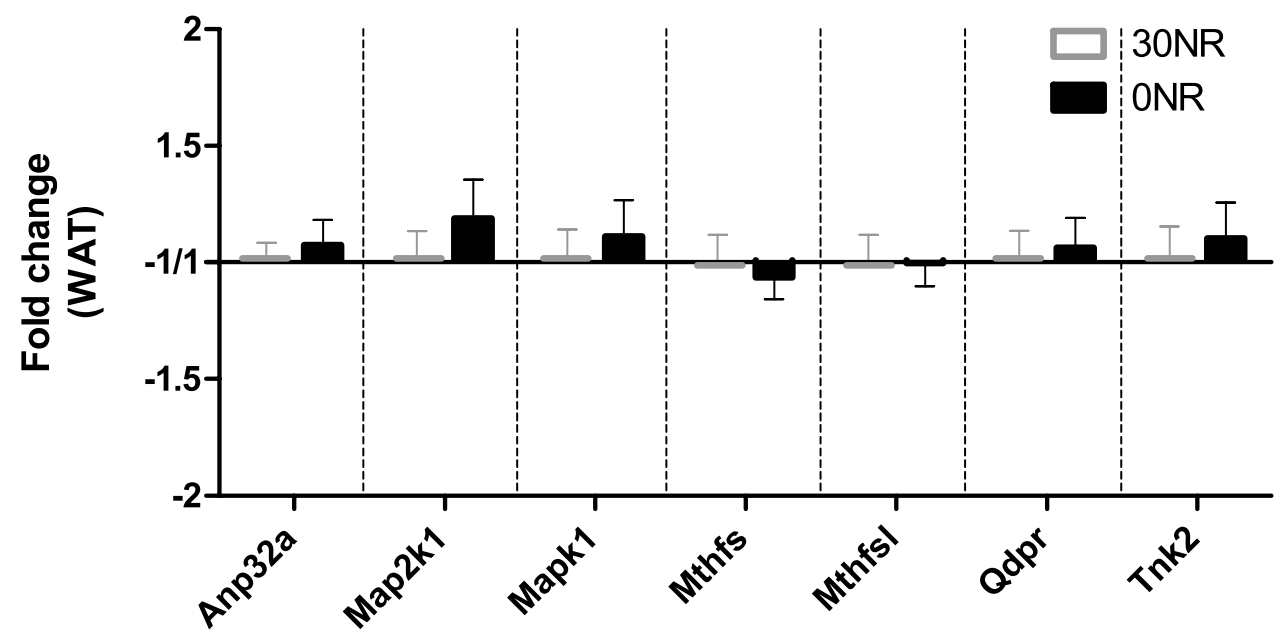

Fig. 3 Expression of seven vitamin $\mathrm{B}_{3}$ responsive genes in white adipose tissue at the end of the study ( $t=18$ weeks), between control mice with a diet of $30 \mathrm{mg} \mathrm{NR} / \mathrm{kg}$ diet (30NR) and $0 \mathrm{mg} \mathrm{NR} / \mathrm{kg}$ diet $(0 \mathrm{NR})$. Anp32a = acidic (leucine-rich) nuclear phosphoprotein 32 family, member A, Map2k1 = mitogen-activated protein kinase kinase
1, Mapk1 = mitogen-activated protein kinase 1, Mthfs $=5,10$-methenyltetrahydrofolate synthetase, Mthfsl $=5,10$-methenyltetrahydrofolate synthetase-like, Qdpr=quinoid dihydropteridine reductase, Tnk2 =tyrosine kinase, non-receptor, 2. Values are means \pm SEM $(n=12)$
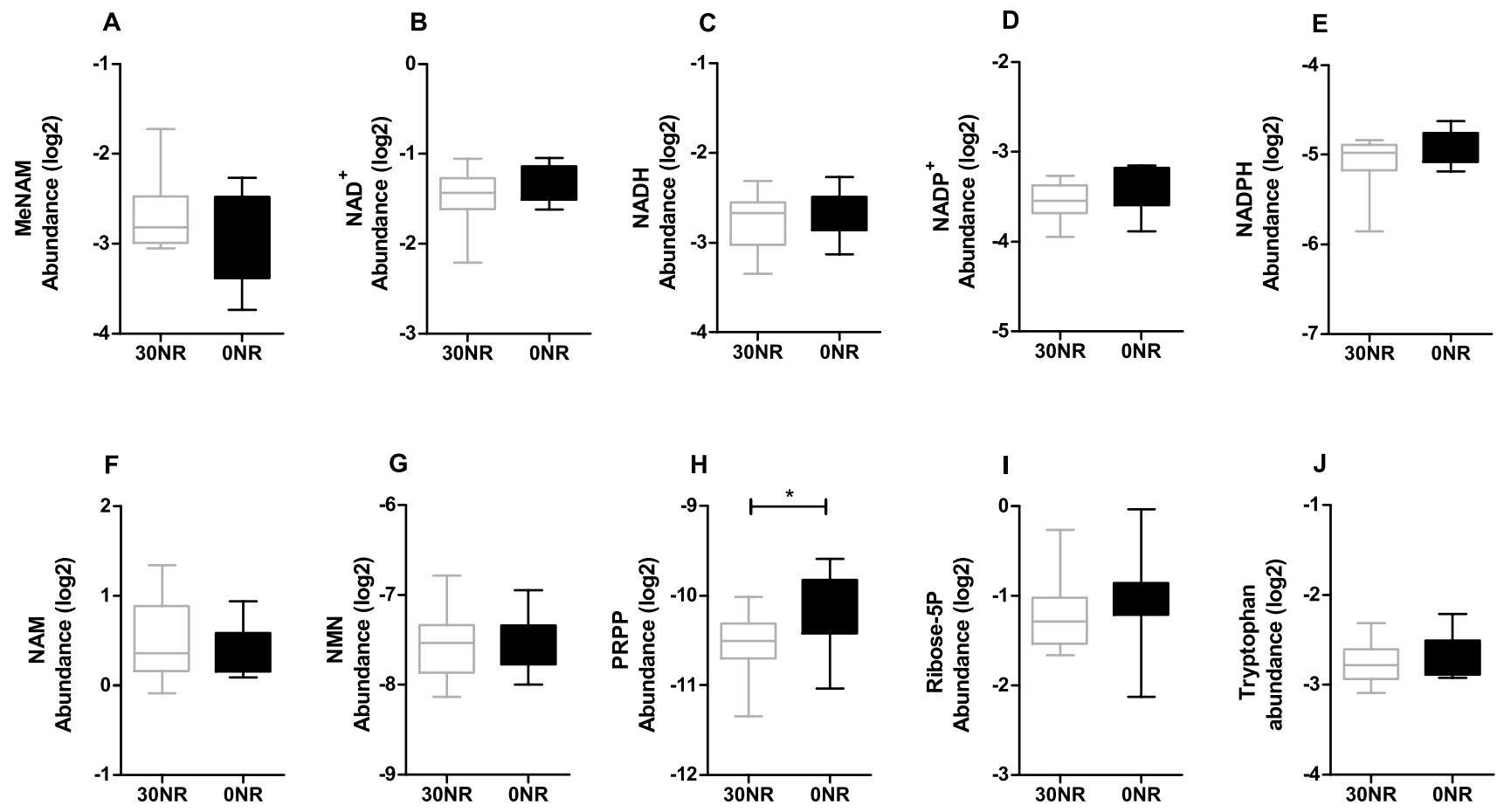

Fig. $4 \mathrm{NAD}^{+}$metabolite abundances measured in liver of control mice on a $30 \mathrm{mg} \mathrm{NR} / \mathrm{kg}$ diet compared to mice on a $0 \mathrm{mg} \mathrm{NR} / \mathrm{kg}$ diet $(t=18$ weeks). a Methylnicotinamide (MeNAM), b nicotinamide adenine dinucleotide (NAD), $\mathbf{c}$ NADH, d NADP, e NADPH, f nico-

since NMN levels were not affected in the female mice, we evaluated insulin sensitivity in the female deficiency model, as this was the most important physiological parameter of male mild vitamin $\mathrm{B}_{3}$ deficiency. Fasting blood glucose levels were not significantly different between 30 and $0 \mathrm{NR}$ tinamide (NAM), g nicotinamide mononucleotide (NMN), $\mathbf{h}$ phosphoribosyl pyrophosphate (PRPP), i Ribose-5 phosphate (ribose-5P), j Tryptophan. Significant differences of $p<0.05$ are indicated with *. Values are means $\pm \operatorname{SEM}(n=12)$

female mice (Fig. 5A/C), neither were circulating glucose levels during the oral glucose tolerance test in female mice on the 0NR diet, compared to female mice the 30NR diet after a glucose bolus (Fig. 5A). Similarly, in the female mice fasting circulating insulin levels and circulating insulin 
A

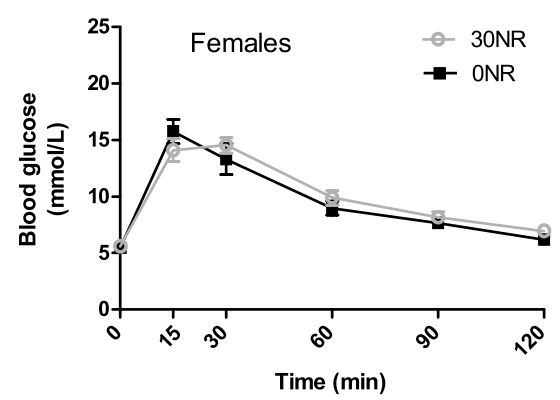

E

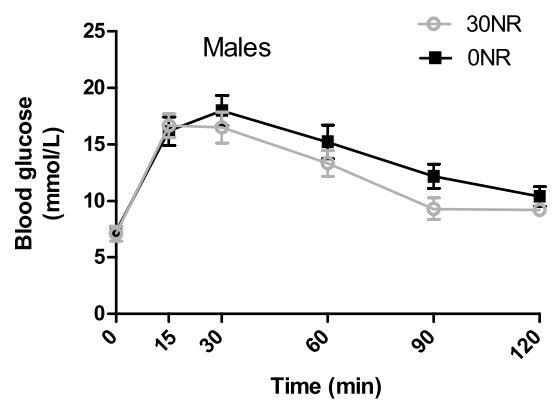

B

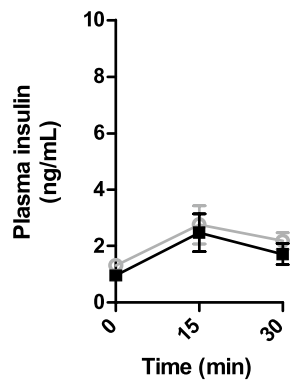

$\mathbf{F}$

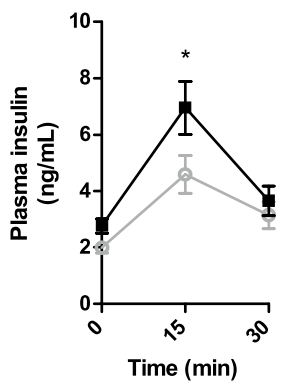

C

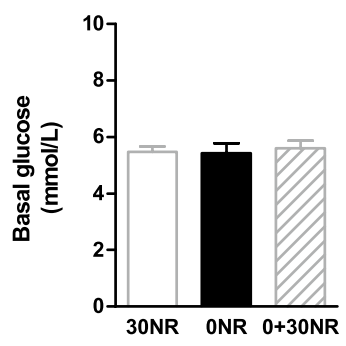

G

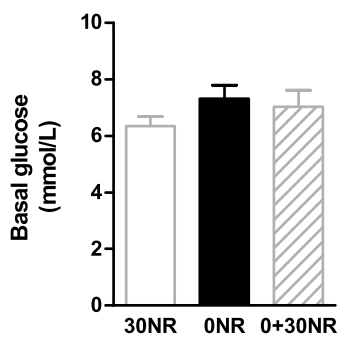

D

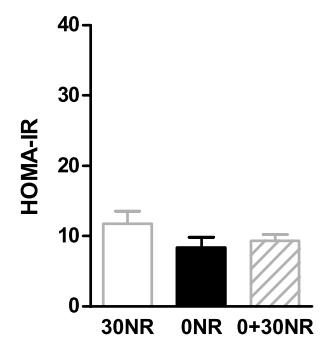

H

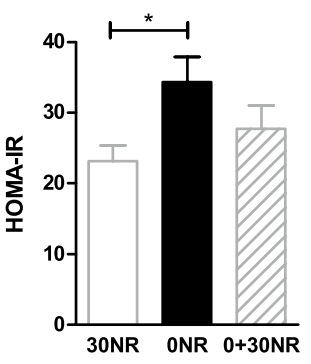

Fig. 5 Results of the oral glucose tolerance test and related plasma insulin levels and HOMA-IR of female mice a-d) fed a diet containing the recommended dose of $30 \mathrm{mg} \mathrm{NR} / \mathrm{kg}$ diet (30NR), no NR/ $\mathrm{kg}$ of diet (0NR), or no NR for 15 weeks followed by 3 weeks of $30 \mathrm{mg} / \mathrm{kg}$ diet $(0+30 \mathrm{NR})$; for comparison the data of the male mice e-h) has been added (published in [17], permission for reproduction

levels during the oral glucose tolerance test were not different between the 30NR and 0NR groups (Fig. 5B). Fasting circulating glucose and insulin levels and circulating glucose response during the oral glucose tolerance test were also not different in male mice on 30NR and 0NR (Fig. 5E-G, [17]). However, the circulating insulin response in the male mice was significantly different in the 0NR compared to the 30NR group (Fig. 5F, [17]). The calculated HOMA-IR, a surrogate marker for insulin sensitivity, was not different between the 0NR and 30NR female mice (Fig. 5D), while previously a clear significant worsening of HOMA-IR was noticed in the $0 \mathrm{NR}$ male mice compared to the control 30NR group (Fig. 5H, [17]). Furthermore, while the glucose transporter Glut4 (Slc2a4) tended to be lower expressed in the 0NR male mice compared to the 30NR male mice ( $\mathrm{FC}=-1.49$, $p=0.07,[17])$, Glut 4 tended to be slightly higher expressed in white adipose tissue of the 0NR female mice compared to the 30NR female mice ( $\mathrm{FC}=1.09, p=0.09$ ).

To confirm deficiency status in females and males, we switched an additional group of mice after 15 weeks on the 0NR diet for 3 weeks to the control 30NR diet. In female granted). $\mathbf{a}$ and $\mathbf{e}$ Oral glucose tolerance test, $\mathbf{b}$ and $\mathbf{f}$ plasma insulin levels during the oral glucose tolerance test in week 17 at timepoints 0,15 and $30 \mathrm{~min}, n=4-7$ for females $n=11-12$ for males, $\mathbf{c}$ and $\mathbf{g}$ basal glucose levels, $\mathbf{d}$ and $\mathbf{h}$ calculated HOMA-IR, using fasted (basal) glucose and insulin levels $(t=0)$. Values are means \pm SEM, $n=12$ unless stated otherwise)

mice, the $0+30 \mathrm{NR}$ group did not show any significant differences compared to continuous feeding with $30 \mathrm{mg} \mathrm{NR} / \mathrm{kg}$ diet (30NR). In contrast, the worsening of HOMA-IR values of the male mice after 18 weeks on the 0NR diet compared to that of the male mice on the 30NR diet, was prevented in the $0+30 \mathrm{NR}$ group, which displayed a HOMA-IR comparable to that of the control 30NR group (Fig. 5H). Together, our data indicate that female mice, different from male mice on the same diet, were not vitamin $\mathrm{B}_{3}$ deficient in this study.

\section{Discussion}

Female mice that were given a diet without vitamin $B_{3}$ were not different from mice fed the recommended level of vitamin $B_{3}$ regarding body composition, energy metabolism, metabolic flexibility, hepatic triacylglycerols and circulating free fatty acids. Next to this, the expression in white adipose tissue of seven genes, responding to mild vitamin $B_{3}$ deficiency, were not differentially expressed in female mice with NR or without NR in their diets. Hepatic NMN levels, 
which were lower in livers of male mice on the same vitamin $\mathrm{B}_{3}$ deficient diet for the same period, were not affected in the female mice. Lastly, the female mice on the 0NR diet did not have a higher HOMA-IR value compared to the female mice on the $30 \mathrm{NR}$ diet, in contrast to the male mice that were fed the 0NR diet for the same duration which showed a higher HOMA-IR value, indicating a higher insulin resistance, compared to male mice on the 30NR diet. The worsening of the HOMA-IR value in the ONR males was not seen when the mice were given 30NR during the last 3 weeks $(0+30 \mathrm{NR})$, supporting that the adverse HOMA-IR values in $0 \mathrm{NR}$ males were due to vitamin $\mathrm{B}_{3}$ deficiency. There were no effects observed in the female mice. Together, these data show that female mice are more resistant to vitamin $B_{3}$ deficiency, compared to male mice of the same strain under the same conditions.

\section{Tryptophan levels}

Investigating effects of (pure) vitamin $\mathrm{B}_{3}$ deficiency is complicated by the fact that tryptophan can serve as an alternative source for $\mathrm{NAD}^{+}$[26]. Tryptophan, being an essential amino acid, cannot be left out of a diet as it is not only functional in the de novo synthesis of $\mathrm{NAD}^{+}$, but also serves an essential function in protein synthesis and serotonin metabolism [27]. For example, complete depletion of tryptophan from the diet for 32 days led to decreased body weight and decreased serotonin neurotransmission [28]. While the recommended amount of tryptophan in the AIN93 rodent diets is $0.21 \%$ for growing animals and $0.16 \%$ for adult animals [18], this is an excess that may mask effects of vitamin $B_{3}$ deficiency. The dietary tryptophan level of $0.115 \%$ used in this study was chosen to be just above the minimal amount of tryptophan needed for processes unrelated to vitamin $\mathrm{B}_{3}$, such as serotonin metabolism, since we wanted to assess vitamin $\mathrm{B}_{3}$ deficiency, while maintaining tryptophan sufficiency. The level chosen was based on previous studies; for example, male Fischer-344 rats fed a $0.11 \%$ tryptophan diet with no added vitamin $B_{3}$ for 3 weeks seemed healthy, but had decreased $\mathrm{NAD}^{+}$levels in blood, liver and other tissues compared to controls fed a vitamin $\mathrm{B}_{3}$ containing diet, showing that this level of tryptophan does affect the $\mathrm{NAD}^{+}$levels without inducing clinical symptoms [29]. Our mice did not show any visible signs of distress, impaired health or, upon dissection, tissue/organ abnormalities, indicating tryptophan sufficiency. This is strengthened by unaffected hydrogen and methane excretion, each of which would be indicative for an altered intestinal microbial activity. An abnormal microbiota activity could indicate a dysbalanced $\mathrm{NAD}^{+}$producing kynurenine pathway, which might be linked to insulin resistance and metabolic syndrome [30]. Also, the glucose and insulin response curves during the oral glucose tolerance test as well as the HOMA-IR values were comparable to that of mice on a similar diet with recommended (AIN93) levels of tryptophan [31]. Together, these results indicate that the $0.115 \%$ tryptophan in the diet of the female mice was low, but sufficient. In fact, there is a possibility that the tryptophan levels used in this study are slightly higher than what is absolutely necessary. This could result in a masking effect for vitamin $B_{3}$ deficiency, resulting in no measurable differences between the two groups of female mice, but it would not explain the differences between the female and male mice, which received identical diets.

\section{$\mathrm{NAD}^{+}$metabolism}

Complete or near-complete elimination of $\mathrm{NAD}^{+}$precursors in the diet has severe effects. For example, middle-aged (12-months old) male mice lacking an active nicotinamide phosphoribosyltransferase (NAMPT), enzyme in the salvage pathway, had lower hepatic $\mathrm{NAD}^{+}$levels and showed increased liver triacylglycerol levels, which were restored when the mice were supplemented with NR [32]. Furthermore, $Q_{p r t}^{-1-}$ mice, deficient in the enzyme quinolinate phosphoribosyltransferase (Qprt) which is involved in the de novo NAD + synthesis pathway, showed lower blood and liver $\mathrm{NAD}^{+}$levels after 23 days, as well as a decrease in body weight within 2 weeks when fed a diet with only tryptophan as a source for $\mathrm{NAD}^{+}$, compared to a nicotinic acid containing diet and compared to wildtype mice on either diet as measured in mixed-sex groups [33]. This indicates that depletion of $\mathrm{NAD}^{+}$pools is reached within 2 weeks when neither vitamin $B_{3}$ nor tryptophan is available for synthesis of $\mathrm{NAD}^{+}$, while either tryptophan or vitamin $\mathrm{B}_{3}$ availability can rescue the deficiency.

Here, in female mice fed a diet with $0.015 \%$ tryptophan and without vitamin $\mathrm{B}_{3}$ for 18 weeks, hepatic $\mathrm{NAD}(\mathrm{P})^{+}$and $\mathrm{NAD}(\mathrm{P}) \mathrm{H}$ levels were not affected compared to mice fed the same diet containing vitamin $\mathrm{B}_{3}$ (Fig. 4). This might be explained by an adaptation effect, since it has been previously reported for rats on a diet with either $0.09 \%$ or $0.11 \%$ tryptophan that $\mathrm{NAD}^{+}$levels were decreased after 3 weeks, but no longer after 5 weeks [29]. Similar to the females in this study, the male mice in our previous study did not have decreased liver or white adipose tissue $\mathrm{NAD}^{+}$levels after 18 weeks on a diet with $0.115 \%$ tryptophan and without vitamin $B_{3}$ [17]. In the male mice a lower level of NMN in the liver was observed in 0NR, compared to 30NR [17], while hepatic NMN levels were indistinguishable between 30 and 0 NR in the female mice of this study (Fig. 4). Also, several other $\mathrm{NAD}^{+}$-related metabolites measured in the liver were not different between the $0 \mathrm{NR}$ and $30 \mathrm{NR}$ female mice, except for PRPP, which was increased in the 0NR mice compared to the 30NR control mice. Regretfully, we previously did not analyse PRPP in the male mice. PRPP plays an important role in both the Preiss-Handler pathway 
and the salvage pathway of $\mathrm{NAD}^{+}$production, as a co-substrate to generate nicotinic acid mononucleotide (NaMN) and NMN, respectively. Therefore, increased PRPP levels could be a compensatory mechanism under circumstances of low NMN or $\mathrm{NAD}^{+}$precursors. Next to its role in $\mathrm{NAD}^{+}$ synthesis, PRPP is also required for purine and pyrimidine synthesis, and a relation between purine/pyrimidine synthesis and $\mathrm{NAD}^{+}$production has been established decades ago [34]. Differences in PRPP levels between the ONR and 30NR female mice of our study could therefore also be related to purine/pyrimidine synthesis, similar to a recent study which showed increased de novo purine synthesis in siRNA transfected NAMPT deficient cells [35]. Overall, our data suggest that the female mouse is more resistant to vitamin $\mathrm{B}_{3}$ deficiency, because NR depletion from the diet results in a compensatory PRPP level aligned with an efficient recycling of $\mathrm{NAD}^{+}$, keeping NMN levels constant.

\section{Severity of vitamin $B_{3}$ deficiency is linked to aging, diet and sex}

\section{Aging}

There are several factors influencing the development and the severity of vitamin $B_{3}$ deficiency, one of which is age. Aged female mice were shown to be more susceptible to high-fat diet induced diabetes compared to young females [36], showing that older mice are more vulnerable for e.g. higher blood glucose levels. Next to this, without lowering vitamin $\mathrm{B}_{3}$ or tryptophan dietary levels, decreased $\mathrm{NAD}^{+}$levels were found in aged mice of 20-24-months old compared to mice of 4-6 months of age in liver and/ or muscle tissue [32, 37, 38], in 24-months old compared to 3 or 12-months old female Wistar rats in liver, heart kidney and lung [14] and in liver or skin tissue of elderly humans $[32,39]$. Furthermore, tryptophan 2,3-dioxygenase levels, involved in the conversion of tryptophan to $\mathrm{NAD}^{+}$, was lower in 18-month-old rats, compared to 2-3-months-old rats [40]. Therefore, it may be that the conditions applied in this study were sufficient to maintain vitamin $B_{3}$ status in the relatively young female mice used here, which were 7-months old at the end of the study, while this may not have been the case in old mice with increased needs.

\section{Diet}

Another $\mathrm{NAD}^{+}$deficiency determining factor is diet and diet-related health. Calorie restriction (30-40\%), also increasing longevity, was shown to prevent the age-related decline in muscle $\mathrm{NAD}^{+}$levels of 22-month-old mice [37]. On the other hand, high-fat diet-induced diabetic mice showed impaired glucose tolerance and lower liver and white adipose tissue $\mathrm{NAD}^{+}$levels compared to chow-fed mice [36]. Interestingly, NMN or NR could counteract the age-induced or diet-induced effects on glucose tolerance, $\mathrm{NAD}^{+}$levels, or fat mass [10, 36, 37]. In liver-specific nicotinamide riboside kinase 1 knockout mice, which are unable to metabolise NR in their liver, high-fat diet feeding resulted in declined $\mathrm{NAD}^{+}$levels, which was not seen with low-fat diet feeding, indicating that NR is necessary in challenging situations when there is an increased need for $\mathrm{NAD}^{+}$[41]. As described above, the females in this study did not show any adverse health signs and may thus not be sufficiently challenged to observe effects of the low vitamin $B_{3}$ and tryptophan intakes.

\section{Sex}

Although most studies in literature have focussed on male mice, this study used female mice. Female mice have been shown to be less prone to the development of diet-induced obesity and insulin resistance; males have different expression profiles of genes involved in the insulin signalling pathway and increased inflammation compared to female mice $[19,20]$. Indeed, this study showed lower (basal) glucose and insulin levels during the oral glucose tolerance test, and lower HOMA-IR values in females compared to males fed the same diet (Fig. 5). Next to this, females fed a high-fat diet developed diabetes (based on blood glucose levels) after 6 months, while this was seen in males after 3.5 months [36]. On a normal (chow) diet about $15 \%$ of 15-26-monthsold male mice developed age-related diabetes, while this was hardly seen in females [36]. Also, glucose tolerance was completely rescued by NMN administration in diabetic female mice, while in male mice this rescue effect was partial. These results are in line with our results, where male mice on the vitamin $\mathrm{B}_{3}$ deficient diet showed insulin resistance, a mildly impaired metabolic flexibility and differential expression in white adipose tissue of seven vitamin $B_{3}$ responsive genes [17], while females fed the same period the same 0NR diet did not display these adverse health signs; their insulin sensitivity (Fig. 5), metabolic flexibility (Fig. 1), and white adipose tissue gene expression of the seven vitamin $\mathrm{B}_{3}$ responsive genes (Fig. 3) was comparable to these parameters in the $30 \mathrm{NR}$ control female mice.

\section{Conclusion}

In conclusion, the female mice in this study did not develop any sign of vitamin $\mathrm{B}_{3}$ deficiency after 18 weeks on a $0.115 \%$ tryptophan containing diet without vitamin $B_{3}$, being resistant to development of vitamin $\mathrm{B}_{3}$ mild deficiency. We propose that the development and severity of a vitamin $B_{3}$ deficiency is linked to age, (dietary) health status and sex. 
This study particularly shows that, to gain valid research data, we should focus our research on both sexes.

In prospect, as more evidence is becoming available linking vitamin $\mathrm{B}_{3}$ deficiency to age-related health problems such as dementia, possibly even linked to an early life vitamin $B_{3}$ deficiency affecting brain development [42], mild, subclinical or temporary vitamin $\mathrm{B}_{3}$ deficiency could have more detrimental effects on health than we are aware of. Thus, exploring vitamin $\mathrm{B}_{3}$ deficiency, including development of good models and detection methods for males and females, seems to be of great importance.

Supplementary Information The online version contains supplementary material available at https://doi.org/10.1007/s00394-021-02651-8.

Funding WS is supported by a Chinese Scholarship Council, Grant Number: \#201303250054. RZP is supported by a postdoctoral grant from the European Union's Horizon 2020 research and innovation programme. Marie Skłodowska-Curie Grant Agreement Number 840110.

Availability of data and material All data and materials support their published claims and comply with field standards.

Code availability Not applicable.

\section{Declarations}

Conflict of interest All authors declare no conflict of interest.

Ethics approval The animal experiment was ethically approved (DEC2016033b) and performed in full accordance with national and EU regulations.

Consent to participate Not applicable.

Consent for publication Male 0NR and 30NR data used in Fig. 5 were published previously, and have been added for comparison purposes, with permission for reproduction from the original journal.

Open Access This article is licensed under a Creative Commons Attribution 4.0 International License, which permits use, sharing, adaptation, distribution and reproduction in any medium or format, as long as you give appropriate credit to the original author(s) and the source, provide a link to the Creative Commons licence, and indicate if changes were made. The images or other third party material in this article are included in the article's Creative Commons licence, unless indicated otherwise in a credit line to the material. If material is not included in the article's Creative Commons licence and your intended use is not permitted by statutory regulation or exceeds the permitted use, you will need to obtain permission directly from the copyright holder. To view a copy of this licence, visit http://creativecommons.org/licenses/by/4.0/.

\section{References}

1. Canto C, Menzies KJ, Auwerx J (2015) NAD(+) metabolism and the control of energy homeostasis: a balancing act between mitochondria and the nucleus. Cell Metab 22(1):31-53. https://doi.org/ 10.1016/j.cmet.2015.05.023
2. Houtkooper RH, Canto C, Wanders RJ, Auwerx J (2010) The secret life of NAD+: an old metabolite controlling new metabolic signaling pathways. Endocr Rev 31(2):194-223. https://doi.org/ 10.1210/er.2009-0026

3. Bieganowski P, Brenner C (2004) Discoveries of nicotinamide riboside as a nutrient and conserved NRK genes establish a PreissHandler independent route to $\mathrm{NAD}^{+}$in fungi and humans. Cell 117(4):495-502. https://doi.org/10.1016/s0092-8674(04)00416-7

4. Ratajczak J, Joffraud M, Trammell SA, Ras R, Canela N, Boutant M, Kulkarni SS, Rodrigues M, Redpath P, Migaud ME, Auwerx J, Yanes O, Brenner C, Canto C (2016) NRK1 controls nicotinamide mononucleotide and nicotinamide riboside metabolism in mammalian cells. Nat Commun 7:13103. https://doi.org/10.1038/ ncomms 13103

5. Altschul R, Hoffer A, Stephen JD (1955) Influence of nicotinic acid on serum cholesterol in man. Arch Biochem Biophys 54(2):558-559. https://doi.org/10.1016/0003-9861(55)90070-9

6. Canner PL, Berge KG, Wenger NK, Stamler J, Friedman L, Prineas RJ, Friedewald W (1986) Fifteen year mortality in coronary drug project patients: long-term benefit with niacin. J Am Coll Cardiol 8(6):1245-1255. https://doi.org/10.1016/s07351097(86)80293-5

7. Carlson LA (2005) Nicotinic acid: the broad-spectrum lipid drug. A 50th anniversary review. J Intern Med 258(2):94-114. https:// doi.org/10.1111/j.1365-2796.2005.01528.x

8. Grundy SM, Mok HY, Zech L, Berman M (1981) Influence of nicotinic acid on metabolism of cholesterol and triglycerides in man. J Lipid Res 22(1):24-36

9. Meyers CD, Kamanna VS, Kashyap ML (2004) Niacin therapy in atherosclerosis. Curr Opin Lipidol 15(6):659-665. https://doi. org/10.1097/00041433-200412000-00006

10. Canto C, Houtkooper RH, Pirinen E, Youn DY, Oosterveer MH, Cen Y, Fernandez-Marcos PJ, Yamamoto H, Andreux PA, Cettour-Rose P, Gademann K, Rinsch C, Schoonjans K, Sauve AA, Auwerx J (2012) The NAD(+) precursor nicotinamide riboside enhances oxidative metabolism and protects against high-fat dietinduced obesity. Cell Metab 15(6):838-847. https://doi.org/10. 1016/j.cmet.2012.04.022

11. Elvehjem CA, Madden RJ, Strong FM, Woolley DW (1937) Relation of nicotinic acid and nicotinic acid aminde to canine black tongue. J Am Chem Soc 59:1767-1768

12. Goldberger J (1918) Pellagra: its nature and prevention. Public Health Rep 33(14):481-488

13. Shi W, Hegeman MA, van Dartel DAM, Tang J, Suarez M, Swarts H, van der Hee B, Arola L, Keijer J (2017) Effects of a wide range of dietary nicotinamide riboside (NR) concentrations on metabolic flexibility and white adipose tissue (WAT) of mice fed a mildly obesogenic diet. Mol Nutr Food Res. https://doi.org/10. 1002/mnfr.201600878

14. Braidy N, Guillemin GJ, Mansour H, Chan-Ling T, Poljak A, Grant R (2011) Age related changes in NAD+ metabolism oxidative stress and Sirt 1 activity in wistar rats. PLoS ONE 6(4):e19194. https://doi.org/10.1371/journal.pone.0019194

15. Qin W, Yang T, Ho L, Zhao Z, Wang J, Chen L, Zhao W, Thiyagarajan M, MacGrogan D, Rodgers JT, Puigserver P, Sadoshima J, Deng H, Pedrini S, Gandy S, Sauve AA, Pasinetti GM (2006) Neuronal SIRT1 activation as a novel mechanism underlying the prevention of Alzheimer disease amyloid neuropathology by calorie restriction. J Biol Chem 281(31):21745-21754. https://doi.org/ 10.1074/jbc.M602909200

16. Wang XN, Hu XJ, Yang Y, Takata T, Sakurai T (2016) Nicotinamide mononucleotide protects against beta-amyloid oligomerinduced cognitive impairment and neuronal death. Brain Res 1643:1-9. https://doi.org/10.1016/j.brainres.2016.04.060

17. Shi WB, Hegeman MA, Doncheva A, van der Stelt I, Bekkenkamp-Grovenstein M, van Schothorst EM, Brenner C, de Boer 
VCJ, Keijer J (2019) Transcriptional response of white adipose tissue to withdrawal of vitamin B3. Mol Nutr Food Res. https:// doi.org/10.1002/mnfr.201801100

18. Reeves PG, Nielsen FH, Fahey GC Jr (1993) AIN-93 purified diets for laboratory rodents: final report of the American Institute of Nutrition ad hoc writing committee on the reformulation of the AIN-76A rodent diet. J Nutr 123(11):1939-1951. https://doi.org/ 10.1093/jn/123.11.1939

19. Grove KL, Fried SK, Greenberg AS, Xiao XQ, Clegg DJ (2010) A microarray analysis of sexual dimorphism of adipose tissues in high-fat-diet-induced obese mice. Int J Obes (Lond) 34(6):9891000. https://doi.org/10.1038/ijo.2010.12

20. Pettersson US, Walden TB, Carlsson PO, Jansson L, Phillipson M (2012) Female mice are protected against high-fat diet induced metabolic syndrome and increase the regulatory $\mathrm{T}$ cell population in adipose tissue. PLoS ONE 7(9):e46057. https://doi.org/ 10.1371/journal.pone.0046057

21. Duivenvoorde LP, van Schothorst EM, Swarts HM, Kuda O, Steenbergh E, Termeulen S, Kopecky J, Keijer J (2015) A difference in fatty acid composition of isocaloric high-fat diets alters metabolic flexibility in male C57BL/6JOlaHsd mice. PLoS ONE 10(6):e0128515. https://doi.org/10.1371/journal.pone.0128515

22. van Dijk TH, Laskewitz AJ, Grefhorst A, Boer TS, Bloks VW, Kuipers F, Groen AK, Reijngoud DJ (2013) A novel approach to monitor glucose metabolism using stable isotopically labelled glucose in longitudinal studies in mice. Lab Anim 47(2):79-88. https://doi.org/10.1177/0023677212473714

23. Bustin SA, Benes V, Garson JA, Hellemans J, Huggett J, Kubista M, Mueller R, Nolan T, Pfaffl MW, Shipley GL, Vandesompele J, Wittwer CT (2009) The MIQE guidelines: minimum information for publication of quantitative real-time PCR experiments. Clin Chem 55(4):611-622. https://doi.org/10.1373/clinchem.2008. 112797

24. Molenaars M, Janssens GE, Williams EG, Jongejan A, Lan J, Rabot S, Joly F, Moerland PD, Schomakers BV, Lezzerini M, Liu YJ, McCormick MA, Kennedy BK, van Weeghel M, van Kampen AHC, Aebersold R, MacInnes AW, Houtkooper RH (2020) A conserved mito-cytosolic translational balance links two longevity pathways. Cell Metab 31(3):549-563. https://doi.org/10.1016/j. cmet.2020.01.011

25. Fernandez-Calleja JMS, Konstanti P, Swarts HJM, Bouwman LMS, Garcia-Campayo V, Billecke N, Oosting A, Smidt H, Keijer J, van Schothorst EM (2018) Non-invasive continuous real-time in vivo analysis of microbial hydrogen production shows adaptation to fermentable carbohydrates in mice. Sci Rep 8(1):15351. https://doi.org/10.1038/s41598-018-33619-0

26. Terakata M, Fukuwatari T, Kadota E, Sano M, Kanai M, Nakamura T, Funakoshi H, Shibata K (2013) The niacin required for optimum growth can be synthesized from L-tryptophan in growing mice lacking tryptophan-2,3-dioxygenase. J Nutr 143(7):10461051. https://doi.org/10.3945/jn.113.176875

27. Comai S, Bertazzo A, Brughera M, Crotti S (2020) Tryptophan in health and disease. Adv Clin Chem 95:165-218. https://doi.org/ 10.1016/bs.acc.2019.08.005

28. Browne CA, Clarke G, Dinan TG, Cryan JF (2012) An effective dietary method for chronic tryptophan depletion in two mouse strains illuminates a role for 5-HT in nesting behaviour. Neuropharmacology 62(5-6):1903-1915. https://doi.org/10.1016/j.neuro pharm.2011.12.009

29. Rawling JM, Jackson TM, Driscoll ER, Kirkland JB (1994) Dietary niacin deficiency lowers tissue poly(ADP-ribose) and NAD+ concentrations in Fischer-344 rats. J Nutr 124(9):1597-1603. https://doi.org/10.1093/jn/124.9.1597

30. Agus A, Planchais J, Sokol H (2018) Gut microbiota regulation of tryptophan metabolism in health and disease. Cell Host Microbe 23(6):716-724. https://doi.org/10.1016/j.chom.2018.05.003

31. Keipert S, Voigt A, Klaus S (2011) Dietary effects on body composition, glucose metabolism, and longevity are modulated by skeletal muscle mitochondrial uncoupling in mice. Aging Cell 10(1):122-136. https://doi.org/10.1111/j.1474-9726.2010.00648.x

32. Zhou CC, Yang X, Hua X, Liu J, Fan MB, Li GQ, Song J, Xu TY, Li ZY, Guan YF, Wang P, Miao CY (2016) Hepatic NAD(+) deficiency as a therapeutic target for non-alcoholic fatty liver disease in ageing. Br J Pharmacol 173(15):2352-2368. https://doi.org/10. 1111/bph.13513

33. Terakata M, Fukuwatari T, Sano M, Nakao N, Sasaki R, Fukuoka SI, Shibata K (2012) Establishment of true niacin deficiency in quinolinic acid phosphoribosyltransferase knockout mice. J Nutr 142(12):2148-2153. https://doi.org/10.3945/jn.112.167569

34. Ferris GM, Clark JB (1972) The control of nucleic acid and nicotinamide nucleotide synthesis in regenerating rat liver. Biochem J 128(4):869-877. https://doi.org/10.1042/bj1280869

35. Singh RK, van Haandel L, Heruth DP, Ye SQ, Leeder JS, Becker ML, Funk RS (2018) Nicotinamide phosphoribosyltransferase deficiency potentiates the antiproliferative activity of methotrexate through enhanced depletion of intracellular ATP. J Pharmacol Exp Ther 365(1):96-106. https://doi.org/10.1124/jpet.117.246199

36. Yoshino J, Mills KF, Yoon MJ, Imai S (2011) Nicotinamide mononucleotide, a key $\mathrm{NAD}(+)$ intermediate, treats the pathophysiology of diet- and age-induced diabetes in mice. Cell Metab 14(4):528-536. https://doi.org/10.1016/j.cmet.2011.08.014

37. Gomes AP, Price NL, Ling AJ, Moslehi JJ, Montgomery MK, Rajman L, White JP, Teodoro JS, Wrann CD, Hubbard BP, Mercken EM, Palmeira CM, de Cabo R, Rolo AP, Turner N, Bell EL, Sinclair DA (2013) Declining NAD(+) induces a pseudohypoxic state disrupting nuclear-mitochondrial communication during aging. Cell 155(7):1624-1638. https://doi.org/10.1016/j.cell.2013.11.037

38. Mouchiroud L, Houtkooper RH, Moullan N, Katsyuba E, Ryu D, Canto C, Mottis A, Jo YS, Viswanathan M, Schoonjans K, Guarente L, Auwerx J (2013) The NAD(+)/sirtuin pathway modulates longevity through activation of mitochondrial UPR and FOXO signaling. Cell 154(2):430-441. https://doi.org/10.1016/j. cell.2013.06.016

39. Massudi H, Grant R, Braidy N, Guest J, Farnsworth B, Guillemin GJ (2012) Age-associated changes in oxidative stress and NAD+ metabolism in human tissue. PLoS ONE 7(7):e42357. https://doi. org/10.1371/journal.pone.0042357

40. Comai S, Costa CV, Ragazzi E, Bertazzo A, Allegri G (2005) The effect of age on the enzyme activities of tryptophan metabolism along the kynurenine pathway in rats. Clin Chim Acta 360(12):67-80. https://doi.org/10.1016/j.cccn.2005.04.013

41. Sambeat A, Ratajczak J, Joffraud M, Sanchez-Garcia JL, Giner MP, Valsesia A, Giroud-Gerbetant J, Valera-Alberni M, Cercillieux A, Boutant M, Kulkarni SS, Moco S, Canto C (2019) Endogenous nicotinamide riboside metabolism protects against diet-induced liver damage. Nat Commun 10:1-11. https://doi.org/ 10.1038/s41467-019-12262-x

42. Williams AC, Hill LJ, Ramsden DB (2012) Nicotinamide, $\mathrm{NAD}(\mathrm{P})(\mathrm{H})$, and methyl-group homeostasis evolved and became a determinant of ageing diseases: hypotheses and lessons from pellagra. Curr Gerontol Geriatr Res 2012:302875. https://doi.org/ $10.1155 / 2012 / 302875$ 